\title{
Intraocular pressure and its correlation with blood gas parameters in crested caracaras (Caracara plancus) anesthetized with isoflurane and sevoflurane
}

[Pressão intra-ocular e sua correlação com parâmetros hemogasométricos em caracarás (Caracara plancus) anestesiados com isofluorano e sevofluorano]

\author{
A.P. Ribeiro ${ }^{1}$, S.N. Vitaliano ${ }^{1}$, R. Thiesen ${ }^{1}$, A. Escobar ${ }^{1}$, J.P. Duque Ortiz ${ }^{1}$, E.A. Belmonte ${ }^{1}$, \\ K. Werther ${ }^{2}$, J.L. Laus ${ }^{2 *}$ \\ ${ }^{1}$ Aluno de pós-graduação - FCAV-UNESP - Jaboticabal, SP \\ ${ }^{2}$ Faculdade de Ciências Agrárias e Veterinárias - UNESP \\ Via de Acesso Professor Paulo Donato Castellane, s/n \\ 14884-900 - Jaboticabal, SP
}

\begin{abstract}
The intraocular pressure (IOP) and its correlations with arterial carbon dioxide partial pressure $\left(\mathrm{PaCO}_{2}\right)$ and arterial $\mathrm{pH}$ were studied in five crested caracaras (Caracara plancus) anesthetized with isoflurane (ISO) and sevoflurane (SEV). Baseline IOP values were measured in both eyes (M0). Brachial artery was previously catheterized to obtain blood gas and cardiorespiratory analysis. Anesthesia was induced with $5 \%$ ISO and maintained with $2.5 \%$ for 40 minutes. IOP measurements and blood samples were evaluated in different moments until the end of the procedure. After recovering, a second anesthesia was induced with $6 \%$ SEV and maintained with 3.5\%. Parameters were evaluated at the same time points of the previous procedure. IOP reduced significantly $(\mathrm{P}=0.012)$ from $\mathrm{M} 0$ at all time points and no significative changes were observed between ISO and SEV anesthesias. Correlation between IOP and $\mathrm{PaCO}_{2}$ and between PIO and blood $\mathrm{pH}$ were found only for SEV. IOP and blood $\mathrm{pH}$ decreased in parallel with IOP, whereas values of $\mathrm{PaCO}_{2}$ increased in caracaras anesthetized with isoflurane and sevoflurane.
\end{abstract}

Keywords: crested caracara, Caracara plancus, isoflurane, sevoflurane, intraocular pressure, blood gas

\section{RESUMO}

Avaliou-se a pressão intra-ocular (PIO) e estimaram-se as correlações entre PIO e pressão de dióxido de carbono $\left(\mathrm{PaCO}_{2}\right)$ e pH arterial de cinco caracarás (Caracara plancus), anestesiados com isofluorano (ISO) ou sevofluorano (SEV). Valores basais da PIO foram aferidos em ambos os olhos (MO). Cateterizou-se previamente a artéria braquial para obtenção de parâmetros hemogasométricos e cardiorrespiratórios. Anestesia foi induzida com ISO a 5V\% e mantida por 40 minutos com 2,5V\%. PIO $e$ amostras de sangue foram avaliadas em diferentes momentos até o final do procedimento. Após recuperação, uma segunda anestesia foi realizada com SEV a 6\% e mantida com 3,5\%. Os parâmetros foram aferidos nos mesmos momentos estabelecidos previamente. A PIO decresceu significativamente $(P=0,012)$ de $M 0$ em todos os momentos e não houve diferença estatística entre ISO e SEV. Correlações significativas entre $\mathrm{PIO}$ e $\mathrm{PaCO}_{2}$ e entre $\mathrm{PIO}$ e pH sangüineo foram observadas apenas para a anestesia com SEV. O pH sangüíneo decresceu paralelamente a PIO, enquanto a $\mathrm{PaCO}_{2}$ aumentou, em carcarás anestesiados com isofluorano e sevofluorano.

Palavras-chave: carcará, Caracara plancus, isofluorano, sevofluorano, pressão intra-ocular, hemogasometria

Recebido em 26 de março de 2008

Aceito em 10 de novembro de 2008

*Autor para correspondência (corresponding author)

E-mail:jllaus@fcav.unesp.br 


\section{INTRODUCTION}

Intraocular pressure (IOP) is defined as the pressure exerted by the components of the eye against the fibrous tunics, and such parameter must remain stable in ophthalmic surgeries (Artru and Yoshiriro, 1999; Gelatt and Gelatt, 2001). An exacerbated increase in IOP may lead to serious intercurrences in patients with glaucoma and in those with penetrating ocular injury (Sator et al., 1998). Thus, sustain of IOP reduces the risks of vitreous expansion and lens extrusion during cataract surgery (Gelatt and Gelatt, 2001). These authors informed that some anesthetic drugs are able to produce ocular hypertension, notably those that produce marked increases in the central venous pressure and in the episcleral venous pressure. Drugs that directly cause ocular hypotension can also produce ocular hypertension secondary to respiratory depression and acidosis that sometimes occurs with prolonged general anesthesia (Gelatt and Gelatt, 2001). The intraocular vascular tonus is influenced by the partial arterial pressure of carbon dioxide, which may influence the choroidal and retrobulbar blood volumes (Murphy, 1985).

Drugs with sympathetic or parasympathetic actions (such as inhaled anesthetics) can alter the IOP via effects on aqueous humor formation, intraocular blood volume and vascular resistance, extraocular muscle tone, and on the diencephalon. Thus, knowledge of the effects of anesthetic gases on IOP is important (Almeida et al., 2004).

Corneal and lens affections, such as cataract, are commonly found in birds of prey and in others of wild living, forcing them to undergo ophthalmic procedures in cases in which vision is intended (Brooks et al., 1983; Kern et al., 1986; Wilson and Pettifer, 2004; Allgoewer et al., 2006).

The crested caracara (Caracara plancus) is a bird of prey and belongs to the Falconiform order. Its geographic distribution extends from the south of Patagonia to the south of the United States of America. It is considered a long neck and feather falcon, and weights $1 \mathrm{~kg}$, in average (Sick, 1997).
This study evaluated the IOP in crested caracaras (Caracara plancus) before and after isoflurane and sevoflurane anesthesia, and correlated its results with partial arterial pressure of carbon dioxide and blood $\mathrm{pH}$.

\section{MATERIAL E METHODS}

Five crested caracaras were selected and their use was authorized by the Instituto Brasileiro do Meio Ambiente e dos Recursos Naturais Renováveis (IBAMA). The study was approved by the Ethics Committee on Animal Experimentation of the Faculdade de Ciências Agrárias e Veterinárias (FCAV) at the Universidade Estadual Paulista (UNESP), Jaboticabal, São Paulo, and followed the ethical norms of the Association for Research in Vision and Ophthalmology (ARVO; National Institutes of Health, Publications no. 85-23, revised 1985).

All birds, adapted to captivity, were maintained in the wild animal section of the FCAV UNESP, in an appropriate environment, and fed once daily received with water ad libitum.

IOP from left (LE) and right eyes (RE) were measured by means of applanation tonometry ${ }^{1}$, after ophthalmic instillation of proximetacaine ${ }^{2}$. Baseline values were evaluated at a first moment (M0), and only measurements achieving less than $5 \%$ standard deviation by the tonometer were considered.

Anesthetic induction was achieved with 5\% isoflurane $^{3}$ (ISO), being delivered by a facial mask. For maintenance, the ISO concentration was reduced to $2.5 \%$. Arterial dissection and catheterization of the brachial artery were proceeded in order to obtain blood pressure and blood gas analysis ${ }^{4}$.

It was admitted that birds were recovered based on of the normalization of the cardiac and respiratory parameters, as well as normalization of temperature, vocalization, resistance to physical restraint, and state of awakeness. Once recovered, arterial blood sample was collected and evaluated for baseline values of arterial

\footnotetext{
${ }^{1}$ Tono-Pen ${ }^{\circledR}$, Mentor O\&O - Norwell, MA, USA.

${ }^{2}$ Anestalcon ${ }^{\circledR}$, Alcon - São Paulo, Brazil.

${ }^{3}$ Cristália ${ }^{\circledR}$, Itapira - São Paulo, Brazil.

${ }^{4}$ Hemogasômetro ABL $330^{\circledR}$, Radiometer - Copenhagen,

Holland.
} 
carbon dioxide partial pressure $\left(\mathrm{PaCO}_{2}\right)$ and arterial $\mathrm{pH}(\mathrm{M} 0)$. Induction of anesthesia was carried out as previously described, birds were endotrachealy intubated and maintained for 40 minutes with $2,5 \%$ ISO diluted in $100 \%$ oxygen (11/min), using an Ayre's T-piece nonrebreathing circuit and monitored throughout the procedure. Birds were maintained in dorsal recumbency, with their heads in lateral recumbency.

IOP was measured five minutes after the ISO anesthetic induction (M5), and at three different time points (M15. M25. M35), at every 10 minutes, with the last IOP measurement occurring five minutes after the end of the anesthesia (M45). Arterial blood samples were collected at four different time points (M0 to $\mathrm{M} 40$ ) in order to analyze $\mathrm{PaCO} 2$ and blood $\mathrm{pH}$. A second anesthetic procedure, with $6 \%$ sevoflurane $^{5}$ (SEV) for induction and 3.5\% for maintenance, was accomplished. IOP and blood gas parameters were measured at the same time points adopted before.

Collected data were analysed ${ }^{6}$ by one way repeated measures ANOVA and Tuckey as a post-hoc test, aiming to compare means obtained at different moments. Paired Student $t$ test was used to compare the overall mean between ISO and SEV anesthesias. Statiscal significance was set at $\mathrm{P}<0.05$. Person's test was used to access a possible correlation between IOP and $\mathrm{PaCO}_{2}$ or IOP and blood $\mathrm{pH}$.

\section{RESULTS}

Overall mean and standard error of mean $( \pm$ SEM) for IOP at M0 before ISO anesthesia was $13.19 \pm 1.04 \mathrm{mmHg}$, being $15.1 \pm 1.12 \mathrm{mmHg}$ the highest value and $9.16 \pm 1.42 \mathrm{mmHg}$ the lowest value. Before SEV anesthesia (M0), mean \pm SEM of IOP was $14.15 \pm 1.08 \mathrm{mmHg}$ $(16.08 \pm 1.11 \mathrm{mmHg}$, the highest and $11.03 \pm 1.02 \mathrm{mmHg}$, the lowest values). Significative changes between LE and RE were not seen at $\mathrm{M} 0(\mathrm{P}=0.823)$. Significative decrease $(\mathrm{P}=0.012)$ was observed when values at $\mathrm{M} 0$ were compared with the other moments, being the lowest mean $\pm \mathrm{SEM}$ for ISO observed at M1 $(7.04 \pm 1.08 \mathrm{mmHg})$ and the highest at M35

\footnotetext{
${ }^{5}$ Abbottt ${ }^{\circledR}$ Laboratórios - São Paulo, Brazil.

${ }^{6}$ SigmaStat ${ }^{\circledR}$ version 3.0 for Windows - San Jose, CA, USA.
}

$(8.19 \pm 0.97 \mathrm{mmHg})$. In the SEV anesthesia, the lowest mean \pm SEM was seen at M25 $(6.82 \pm 0.55 \mathrm{mmHg})$ and the highest at M15 $(7.92 \pm 1.60 \mathrm{mmHg})$.

During both anesthetic procedures, IOP values between LE and RE did not change significantly at any time points $(\mathrm{P}=0.727)$. In addition, IOP did not vary significantly between ISO $(7.04 \pm 1.08 \mathrm{mmHg})$ and SEV $(8.85 \pm 1.31 \mathrm{mmHg})$ anesthesia, at any of the moments (M5 to M35). Although not significant, IOP tended to reach $1.80 \mathrm{mmHg}$ at M45. during SEV anesthesia. The condition could not be seen when the birds were submitted to ISO anesthesia. Fig. 1 summarizes the results of IOP from M0 to M45.

Table 1 summarizes the results of the evaluated blood gas parameters. Significative increase in values of $\mathrm{PaCO}_{2}$ were seen during both ISO and SEV anesthesias $(\mathrm{P}=0.0022)$. During ISO anesthesia, mean \pm SEM at M0 was $24.32 \pm 2.05 \mathrm{mmHg}$, with the highest value observed at M25 (46.28 $\pm 1.4 \mathrm{mmHg})$. In SEV anesthesia, mean \pm SEM at M0 was $27.56 \pm 2.26 \mathrm{mmHg}$, being the highest result seen at M25 $(43.95 \pm 1.26 \mathrm{mmHg})$. Results did not change significantly when both anesthetic procedures were compared $(\mathrm{P}=0.086)$.

Values of blood $\mathrm{pH}$ significantly decreased during ISO and SEV anesthesias $(\mathrm{P}=0.0034)$. For ISO, mean \pm SEM at M0 was $7.53 \pm 0.02$, being the highest value observed at M40 (7.33 \pm 0.01$)$. During SEV anesthesia, mean \pm SEM in M0 was $7.49 \pm 0.01$, being the highest one observed at M40 (7.35 \pm 0.01$)$. Results did not change significantly when both anesthetic procedures were compared $(\mathrm{P}=0.089)$.

Negative correlation between IOP and $\mathrm{PaCO}_{2}$ was observed during sevoflurane anesthesia $\left(\mathrm{r}^{2}=0.9826 ; \mathrm{P}=0.0087\right)$. Although a high value of root squared was reached for isoflurane, a significative negative correlation between IOP and $\mathrm{PaCO}_{2}$ could not be observed $\left(\mathrm{r}^{2}=0.8767\right.$; $\mathrm{P}=0.0637$ ) (Fig. 2). Similarly, positive correlation was only seen for sevoflurane, when blood $\mathrm{pH}$ and IOP were compared $\left(\mathrm{r}^{2}=0.9917\right.$; $\mathrm{P}=0.0042$ ). For isoflurane, although a high value of root squared was reached, a significative positive correlation could not be observed $\left(r^{2}=0.8891 ; \mathrm{P}=0.0571\right)$ (Fig. 3). 


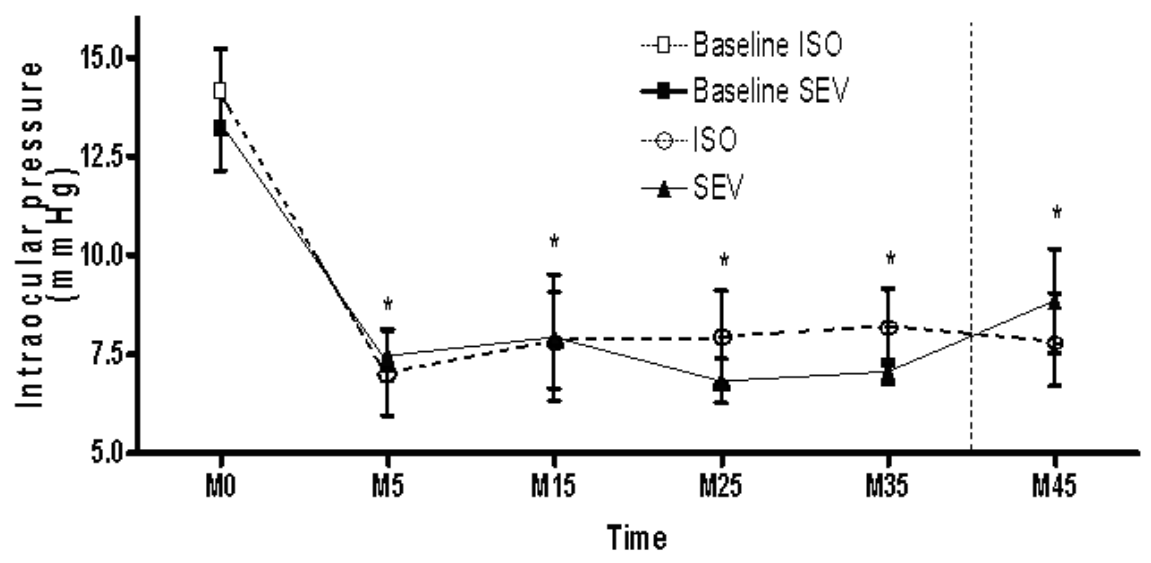

Figure 1. Mean and standard error of mean of intraocular pressure (IOP), at different moments (M0 to M45), from baseline (full and opened squares) throughout 40 minutes of anesthesia (vertical dotted line) in crested caracaras (Caracara plancus) anesthetized with isoflurane (ISO) (opened circle and dotted line) or sevoflurane (SEV) (full pyramid and line). *Differ significantly from M0 by Tukey's test.

Table 1. Mean and standard error of mean $( \pm \mathrm{SEM})$ of arterial carbon dioxide partial pressure $\left(\mathrm{PaCO}_{2}\right)$ and arterial $\mathrm{pH}$ in five crested caracaras (Caracara plancus) anesthetized with isoflurane and sevoflurane at different moments

\begin{tabular}{lcc}
\hline $\begin{array}{c}\text { Anesthetic agent and } \\
\text { moment }(\mathrm{M})\end{array}$ & $\begin{array}{c}\mathrm{PaCO}_{2}(\mathrm{mmHg}) \\
(\mathrm{mean} \pm \mathrm{SEM})\end{array}$ & $\begin{array}{c}\text { Blood pH } \\
(\text { mean } \pm \text { SEM })\end{array}$ \\
\hline Isoflurane M0 & $24.322 \pm 2.057$ & $7.532 \pm 0.0261$ \\
Isoflurane M10 & $40.900 \pm 1.795^{*}$ & $7.381 \pm 0.0151^{*}$ \\
Isoflurane M25 & $43.438 \pm 2.021^{*}$ & $7.360 \pm 0.0156^{*}$ \\
Isoflurane M40 & $46.288 \pm 2.113^{*}$ & $7.337 \pm 0.0154^{*}$ \\
\hline Sevoflurane M0 & $27.563 \pm 2.263$ & $7.494 \pm 0.0168$ \\
Sevoflurane M10 & $41.263 \pm 2.170^{*}$ & $7.379 \pm 0.0121^{*}$ \\
Sevoflurane M25 & $42.513 \pm 1.323^{*}$ & $7.378 \pm 0.0135^{*}$ \\
Sevoflurane M40 & $43.950 \pm 1.260^{*}$ & $7.352 \pm 0.0193^{*}$ \\
\hline
\end{tabular}

*Differ significantly $(\mathrm{P} \leq 0.05)$ from M0 by Tukey's test.
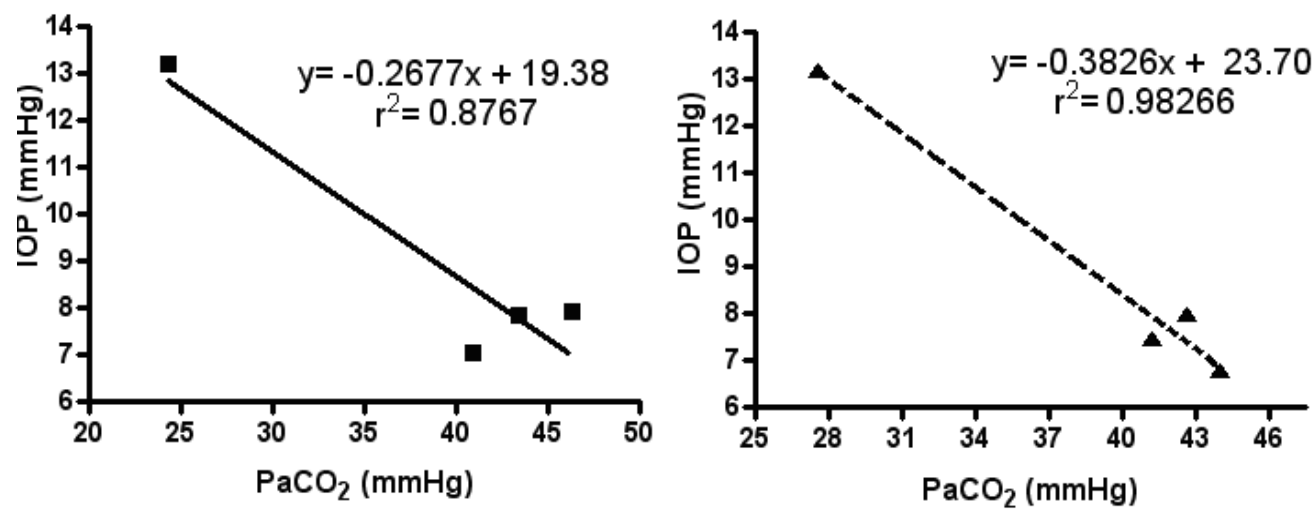

Figure 2. Linear regression curves indicating the regression of intraocular pressure (IOP) values on arterial carbon dioxide partial pressure $\left(\mathrm{PaCO}_{2}\right)$ values in crested caracaras (Caracara plancus) anesthetized with isoflurane (squares) and sevoflurane (pyramids). Dotted line represents the calculated regression in which the negative correlation between measured IOP values and measured $\mathrm{PaCO}_{2}$ values was significant $(\mathrm{P}=0.0087)$. For isoflurane anesthesia (solid line), a correlation was not found $(\mathrm{P}=0.0637)$. 

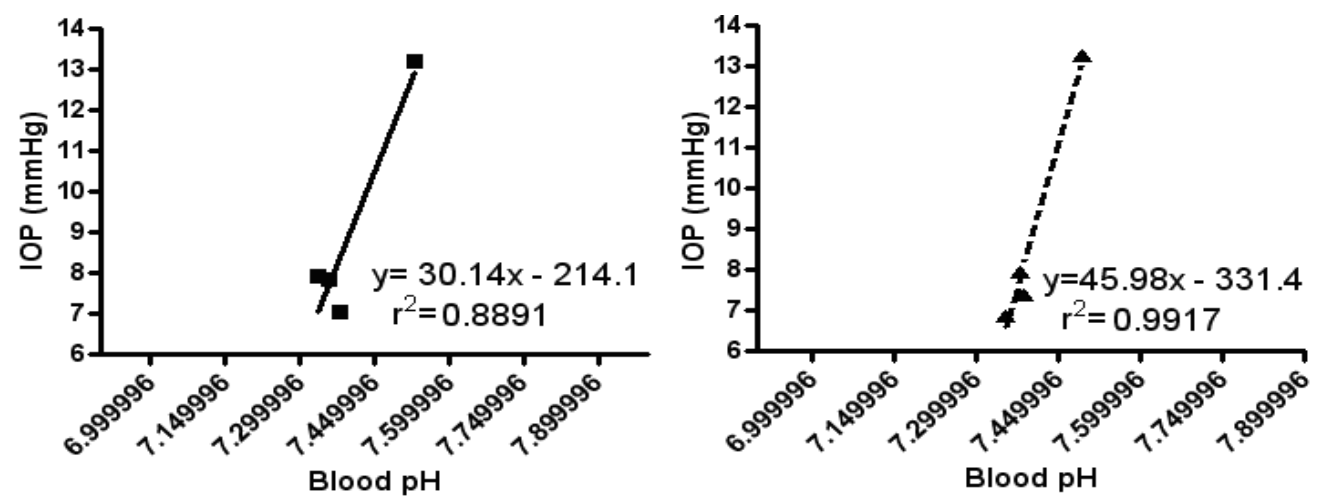

Figure 3. Linear regression curves indicating the regression of intraocular pressure (IOP) values on arterial $\mathrm{pH}$ values in crested caracaras (Caracara plancus) anesthetized with isoflurane (squares) and sevoflurane (pyramids). The dotted line represents the calculated regression in which the positive correlation between measured IOP values and measured blood $\mathrm{pH}$ values was significant $(\mathrm{P}=0.0042)$. For isoflurane anesthesia, (solid line) a correlation was not found $(\mathrm{P}=0.0571)$.

\section{DISCUSSION}

This study showed that both isoflurane and sevoflurane anesthesias decreased IOP values in crested caracaras, in accordance with previous publications on dogs and human beings (Sator et al., 1998). During isoflurane anesthesia, IOP decreased $46 \%$ from baseline values, whereas with sevoflurane, this decrease was $33 \%$. However, no significative difference was observed between the anesthetics agents $(\mathrm{P}=0.727)$. In the course of anesthesia, the reduction in IOP values may be attributed to mechanisms that involve a diminishing in the aqueous humor production in the ciliary body and the enhancement of its outflow by the iridocorneal angle (Artru and Yoshiriro, 1999). External eye compression and hydrostatic events due to recumbency may interfere with IOP measurements (Murphy, 1985; Cunningham and Barry, 1986). However, in these study, neither statistically $(\mathrm{P}=0.727)$ nor clinically significant differences occurred between left and right eyes due to lateral head recumbency in both anesthetic procedures. The limitations of this study may be attributed to the restricted number of subjects used; what can be justified when wild species are employed in researching.

Primary glaucoma is a disease of rare occurrence in birds (Kern, 2003). Even so, the secondary form has already been reported (Kern, 2003; Bras et al., 2005). IOP elevation occurs during intubation and extubation in anesthetic procedures in dogs (Hofmeister et al., 2006).
Although measurement of IOP after extubation has not been done herein, it is reasonable to admit that such intercurrence may have happened. The increase of $1.80 \mathrm{mmHg}$ that occurred five minutes after the end of sevoflurane anesthesia may be attributed to the faster recovering of the birds, once this agent possesses a lower blood/gas partition coefficient in comparison to isoflurane (Nunes et al., 2003).

Even though the present study did not established the behavior of IOP in a daily curve, such parameter featured lower values based in comparison to previously reported values in eagles (Stiles et al., 1994). Birds of prey commonly undergo ophthalmic surgeries (Brooks et al., 1983; Kern et al., 1986; Wilson and Pettifer, 2004; Allgoewer et al., 2006). Knowledge of changes in IOP values during anesthetic procedures add assistance or even determine for the decision by the use of viscoelastic agents in intraocular surgeries. Resistence of the fibrous tunics plays an important role in the maintenance of IOP. Domestic animals, in general, possess lower ocular rigidity than man (Gelatt and Gelatt, 2001). In contrast, the ocular bulbus of birds is formed and maintained by the hyaline cartilage enclosed into the sclera of the posterior segment, and by 10-18 scleral ossicles scattered into the sclera of the intermediary segment (Kern, 2003). Brooks et al. (1983) reported that, in owls, scleral ossicles are capable of maintaining IOP in accepted levels for intraocular surgeries. This 
observation do not corroborates to the findings of the present study.

Factors that influence the inflow and outflow of blood to the eye can change IOP. Variations of intraocular blood flow originate from the intraocular vascular tonus. The intraocular vascular tonus is influenced by the arterial carbon dioxide partial pressure $\left(\mathrm{PaCO}_{2}\right)$, which may influence the choroidal and retrobulbar blood volumes (Murphy, 1985) and by the diencephalon, which could mediate a neurogenic control of extraocular muscle tone (Murphy, 1985).

Gelatt and Gelatt (2001) informed that some anesthetic drugs that are to produce ocular hypotension can also produce ocular hypertension, secondary to respiratory depression and acidosis that sometimes occurs with prolonged general anesthesia. Hypoventilation contributes to the increase in venous blood pressure, with choroidal vasodilatation, causing an elevation in IOP (Duncalf and Weitzner, 1963; Hvidberg et al., 1981). In respiratory alkalosis, diminution of IOP occurs as a consequence of the reduction in the choroidal blood volume, diminution of blood flow to the ciliary body, inhibition of carbonic anhydrase enzyme, and decrease of filtration of the aqueous humor (Smith et al., 1981; Cunningham and Barry, 1986). Nevertheless, the respiratory acidosis that took place in the birds of the present study, did not elicit increase values of IOP.

It was decided to correlate IOP changes with both $\mathrm{PaCO}_{2}$ and arterial $\mathrm{pH}$ because changes in arterial pressure may have a limited effect on IOP (Macri, 1961). As a matter of fact, a significative correlation between IOP and $\mathrm{PaCO}_{2}(\mathrm{P}=0.0087)$ and between IOP and blood $\mathrm{pH}(\mathrm{P}=0.0042)$ was found only for sevoflurane. During isoflurane anesthesia, although the $\mathrm{P}$ values were not significant, the behavior of such parameters can be compared to those found to sevoflurane, and right indexes of root square were achieved $\left(\mathrm{r}^{2}=0.8767\right.$ for IOP $-\mathrm{PaCO}_{2}$; $\mathrm{r}^{2}=0.8891$ for IOP-blood $\left.\mathrm{pH}\right)$.

Almeida et al. (2004) studied normocapneic dogs, anesthetized with sevoflurane and desfluorane, and observed that a significant change in IOP values did not occurre in the course of both procedures, differently from what was noted in human beings anesthetized and maintained under controlled ventilation (Sator et al., 1998). Even though, it is feasible to control respiration during anesthesia in birds (Naganobu et al., 2000), there is no way to predict if such procedure would interfere on the IOP values, once it was not employed in the present study.

In summary, it is reasonable to admit that both isoflurane and sevoflurane anesthesias increase $\mathrm{PaCO}_{2}$ values and decrease IOP and blood $\mathrm{pH}$ values in crested caracaras. In addition, the decline in IOP values seen in this study points to the existence of a positive correlation between IOP and blood $\mathrm{pH}$, but negative between IOP and $\mathrm{PaCO}_{2}$.

\section{REFERENCES}

ALLGOEWER, M.; LIERZ, H.M.; HAFEZ, R. et al. Cataracts in falcons. In: EUROPEAN COLLEGE OF VETERINARY OPHTHALMOLOGISTS AND EUROPEAN SOCIETY OF VETERINARY OPHTHALMOLOGY, Brugge. 2006. Proceedings... Brugge, 2006.

ALMEIDA, D.E.; REZENDE, M.L.; NUNES, $\mathrm{N}$. et al. Evaluation of intraocular pressure in association with cardiovascular parameters in normocapneic dogs anesthetized with sevoflurane and desfluorane. Vet. Ophthalmol., v.7, p.265-269, 2004.

ARTRU, A.; YOSHIRIRO, M. Trabecular outflow facility and formation rate of aqueous humor during anesthesia with sevofluranenitrous oxide or sevoflurane-remifentanil in rabbits. Anesth. Analg., v.88, p.781-786, 1999.

BRAS, I.D.; GEMENSKY-METZLER, A.J.; KUSEWITT, D.F. et al. Immunohistochemical characterization of a malignant intraocular teratoid medulloepithelioma in a cockatiel. Vet. Ophthal., v.8, p.59-65, 2005.

BROOKS, D.E.; MURPHY, C.J.; QUESENBERRY, K.E. et al. Surgical correction of luxaded cataractous lens in a barred owl. J. Am. Vet. Med. Assoc., v.183, p.1298-1299, 1983.

CUNNINGHAM, A.J.; BARRY, P. Intraocular pressure - physiology and implications for 
anaesthetic management. Can. Anaesth. Soc. J., v.33, p.195-208, 1986.

DUNCALF, M.B.; WEITZNER, S.W. Ventilation and hypercapnea on intraocular pressure during anesthesia. Anesth. Analg., v.42, p.232-237, 1963.

GELATT, K.N.; GELATT, J.P. Anesthesia for ophthalmic surgery. In:_ Small animal ophthalmic surgery: practical techniques for the veterinarian. Oxford: Butterworth \& Heinemann, 2001. p.34-44.

HOFMEISTER, E.H.; WILLIAMS， C.O.; BRAUN, C. et al. Influence of lidocaíne and diazepam on peri-induction intraocular pressure in dogs anesthetized with propofol-atracurium. Can. Vet. J., v.70, p.251-156, 2006.

HVIDBERG, A.; KESSING, V.; FERNANDES, A. Effect of changes in $\mathrm{PCO} 2$ and body positions on intraocular pressure during general anaesthesia. Acta Ophthalmol., v.59, p.465-475, 1981.

KERN, T.J. Oftalmologia dos animais exóticos. In: GELATT, K.N. Manual de oftalmologia veterinária. Barueri: Manole, 2003. p.413-438.

KERN, T.J.; MURPHY, C.J.; RIIS, R.C. Lens extraction by phacoemulsification in two raptors. J. Am. Vet. Med. Assoc., v.185, p.14031406, 1986.

MACRI, F.J. Vascular pressure relationship and the intraocular pressure. Arch. Ophthalmol, v.65, p.133-136, 1961.
MURPHY, D.F. Anaesthesia and intraocular pressure. Anesth. Analg., v.64, p.520-530, 1985.

NAGANOBU, K.; FUZISAWA, Y.; OHDE, H. Determination of the miminun anesthetic concentration and cardiovascular dose response for sevoflurane in chickens during controlled ventilation. Vet. Surg., v.29, p.102-105, 2000.

NUNES, N.; MARTINS, S.E.C.; SANTOS, P.S.P. et al. Efeitos do desflurano, sevoflurano e isoflurano sobre o shunt pulmonar em cães sob respiração espontânea. Arq. Bras. Med. Vet. Zootec., v.55, p.173-177, 2003.

SATOR, S.; WILDLING, C.; SCHABERNING, J. et al. Desfluorane maintains intraocular pressure at an equivalent level to isoflurane and propofol during unstressed non-ophthalmic surgery. Br. J. Anesth., v.80, p.243-244, 1998.

SICK, H. Ornitologia brasileira. 3.ed. Rio de Janeiro: Nova Fronteira, 1997. 256p.

SMITH, R.B.; AASS, A.A.; NEMOTO, M. Intraocular and intracranial pressure during respiratory alkalosis and acidosis. Br. J. Anesth., v.53, p.967-972, 1981.

STILES, J.; BUYUKMIHCI, N.C.; FARVER, T.B. Tonometry of normal raptors. Am. J. Vet. Res., v.55, p.477-499, 1994.

WILSON, D.; PETTIFER, G.R. Mallard undergoing phacoemulsification of a cataract. $J$. Am. Vet. Med. Assoc., v.225. p.685-688, 2004. 